\title{
Neuronal Dopamine Subpopulations Maintained in Hypothalamic Slice Explant Cultures Exhibit Distinct Tyrosine Hydroxylase mRNA Turnover Rates
}

\author{
Jennifer A. Maurer and Susan Wray \\ Laboratory of Neurochemistry, National Institute of Neurological Disorders and Stroke, National Institutes of Health, \\ Bethesda, Maryland 20892
}

\begin{abstract}
Changes in mRNA stability have been shown to regulate critical intracellular processes. In this investigation, we studied tyrosine hydroxylase (TH) mRNA turnover in functionally and anatomically distinct dopaminergic (DA) populations of the rat hypothalamus. To this end, long-term slice explant cultures from postnatal, preoptic area/hypothalami, containing three anatomically discrete DA populations, were generated and maintained under defined conditions. The organotypic cultures were treated with the transcription inhibitors 5,6-dichloro-1-Dribofuranosylbenzimidazole or actinomycin $D$ and processed for in situ hybridization histochemistry. Relative TH mRNA content per cell was quantitated. Single-cell analysis showed marked differences in basal TH mRNA turnover rates between DA neuronal populations. Anterior and midhypothalamic DA neurons exhibited half-time turnovers of 9-12 and 11-23 hr, respectively. In contrast, in the caudal hypothalamus, DA neu-
\end{abstract}

rons of the arcuate nucleus had a significantly lower baseline level and more rapid turnover $(6-7 \mathrm{hr})$ of $\mathrm{TH}$ mRNA. This investigation shows that basal turnover of a phenotypic mRNA, TH mRNA in DA neurons, is not an intrinsic property of the phenotypic marker. Furthermore, we found that destabilization of TH mRNA in the caudal hypothalamus corresponds to the known rhythmic output displayed by arcuate DA cells and, as such, may be critical for normal function of this population. We propose that intrinsic differences in the post-transcriptional regulation of $\mathrm{TH}$ permits neuronal subpopulations, which subserve different physiological functions, an additional mechanism to control DA biosynthesis in response to their unique needs.

Key words: gene expression; mRNA stability; organotypic; arcuate nucleus; DRB; actinomycin $D$
Changes in mRNA stability have been shown to regulate critical cellular processes such as expression of early response genes (i.e., c-fos and c-myc) after stimulation by neurotransmitters, cytokines, or growth factors (Greenberg and Belasco, 1993); histone gene expression during cell cycling (Atwater et al., 1990); homeostasis of intracellular iron levels (Klausner et al., 1993); and peptidylglycine $\alpha$-amidating mono-oxygenase gene expression in pituitary tissue by thyroid status (Fraboulet et al., 1996). Examples of mRNA stability as an intracellular regulatory mechanism continue to accumulate; however, the overall importance of this post-transcriptional event in governing cell function is difficult to evaluate because of the complexity of the in vivo state. To circumvent these problems, many investigations have focused on dissociated culture models of catecholaminergic cells. Using such paradigms, changes in the mRNA stability of tyrosine hydroxylase (TH), the rate-limiting enzyme of catecholamine biosynthesis (Levitt et al., 1965), have been associated with neuronal differentiation (Summerhill et al., 1987), hypoxia (Czyzyk-Krzeska et al., 1994a,b), cell-cell contact (Saadat et al., 1987), phorbol ester (Vyas et al., 1990), cAMP analog (Fossom et al., 1992), and cholinergic stimulation (Craviso et al., 1992). However, even in

Received Jan. 28, 1997; revised March 28, 1997; accepted March 31, 1997.

J.A.M. is a Pharmacology Research Associate Fellow, supported by the National Institute of General Medical Sciences, National Institutes of Health.

Correspondence should be sent to Dr. Susan Wray, Section Chief, Cellular and Developmental Neurobiology, Laboratory of Neurochemistry, National Institute of Neurological Diseases and Stroke, National Institutes of Health, Building 36, Room 4D10, Bethesda, MD 20892.

Copyright (C) 1997 Society for Neuroscience $0270-6474 / 97 / 174552-10 \$ 05.00 / 0$ model systems, estimates of basal TH mRNA half-time $\left(t_{1 / 2}\right)$ turnover, a measurement of mRNA stability, show variability ranging from 6 to $16 \mathrm{hr}$ (Vyas et al., 1990; Fossom et al., 1992; Czyzyk-Krzeska et al., 1994a). The variability may result from use of different immortalized cell lines and/or experimental paradigms. In the present study, we circumvent many difficulties associated with in vivo studies, yet focus on primary CNS neurons, by examining turnover of a single mRNA type in postnatal CNS neurons maintained in organotypic cultures under defined conditions. By analyzing phenotypically similar but anatomically discrete neurons with different efferents, this study addresses the hypothesis that neuronal populations expressing a single phenotypic marker, TH, have similar mRNA turnover rates.

Discrete populations of TH-containing neurons (i.e., periventricular, incertohypothalamic, tuberohypophysial, and tuberoinfundibular) are present within the preoptic area/hypothalamus and are central to both endocrine and behavioral functions (Versteeg et al., 1975; Arbogast and Voogt, 1991a; Manzanares et al., 1992; Eaton et al., 1994; Wagner et al., 1994). To isolate anatomically discrete dopaminergic (DA) cell groups and examine $\mathrm{TH}$ mRNA turnover within such populations, long-term slice explant cultures from distinct regions of the preoptic area/hypothalamus were generated and maintained under defined conditions. These cultures retain their neuroanatomical organization and thus allow examination of neurons within an organotypic environment (Wray et al., 1988). In addition, slice explant cultures display characteristics of their in vivo counterparts including changes in gene expression (Wray et al., 1989), mRNA stability (Carter and Murphy, 1989), neurosecretion (Baertschi et al., 1982), and circadian 
rhythms (Tominaga et al., 1994). Using slice explant cultures, in situ hybridization histochemistry (ISHH), and the transcription inhibitors 5,6-dichloro-1-D-ribofuranosylbenzimidazole (DRB) and actinomycin D, this study calculates basal TH mRNA turnover of three anatomically distinct hypothalamic DA populations. We report that DA cells of the arcuate nucleus in the caudal hypothalamus $(\mathrm{CH})$ have a basal TH mRNA turnover of 6-7 hr, whereas those observed in the anterior hypothalamus $(\mathrm{AH})$ and mid-hypothalamus $(\mathrm{MH})$ were $9-12$ and 11-23 hr, respectively. Therefore, baseline stability of a phenotypic mRNA, rather than being conserved among cell populations (classified by that marker), reflects the specialized function(s) of each neuronal subpopulation.

\section{MATERIALS AND METHODS}

Materials. Actinomycin D, DRB, dimethyl sulfoxide (DMSO), D-glucose, apo-transferrin, putrescine, sodium selenite, bovine insulin, and L-ascorbic acid were obtained from Sigma (St. Louis, MO). Eagle basal medium, EBSS, Ham's F-12 nutrient mixture, L-glutamine, PSN antibiotic mixture, and horse serum were obtained from Life Technologies (Grand Island, NY). Boehringer Mannheim (Indianapolis, IN) supplied bovine serum albumin.

Organotypic cultures. Tissue was cultured as slice explants by the rollertube method as described previously (Wray et al., 1988, 1989). Briefly, brains from 5-d-old rat pups were removed, and the preoptic area/ hypothalami were blocked and sectioned at $400 \mu \mathrm{m}$ on a McIlwain tissue slicer. Coronal slices (two from each region) containing DA neurons in preoptic/AH, MH at the level of the paraventricular nucleus, and $\mathrm{CH}$ were separated, placed in Gey's balanced salt solution enriched with glucose, and refrigerated for at least $1 \mathrm{hr}$. Slices were adhered onto glass coverslips by a plasma/thrombin clot, placed in $15 \mathrm{ml}$ Falcon tubes, and rotated in a Bellco roller drum. For optimal thinning, cultures were initially grown in serum-containing media consisting of $25 \%$ heatinactivated horse serum, 50\% Eagle basal medium, 25\% EBSS supplemented with $7.5 \mathrm{mg} / \mathrm{ml}$ glucose, $2 \mathrm{~mm}$ glutamine, $12.5 \mu \mathrm{g} / \mathrm{ml}$ penicillin, $12.5 \mu \mathrm{g} / \mathrm{ml}$ streptomycin, and $25 \mu \mathrm{g} / \mathrm{ml}$ neomycin (Wray et al., 1988). Seven days before experimentation, cultures were transferred to defined media composed of 50\% Eagle's basal media and 50\% Ham's F-12 nutrient mixture supplemented with $10 \mathrm{mg} / \mathrm{ml}$ bovine serum albumin, 100 $\mu \mathrm{M}$ putrescine, $5 \mu \mathrm{g} / \mathrm{ml}$ insulin, $100 \mu \mathrm{g} / \mathrm{ml}$ transferrin, $2 \mathrm{~mm}$ glutamine, $7.5 \mathrm{mg} / \mathrm{ml}$ glucose, $12.5 \mu \mathrm{g} / \mathrm{ml}$ penicillin, $12.5 \mu \mathrm{g} / \mathrm{ml}$ streptomycin, and 25 $\mu \mathrm{g} / \mathrm{ml}$ neomycin (Wray et al., 1989). After $18 \mathrm{~d}$ in culture, the slice explants were treated with vehicle (0.1\% DMSO), $4 \mu \mathrm{M}$ actinomycin D, or $150 \mu \mathrm{M} \mathrm{DRB}$, inhibitors of gene transcription. At the times indicated, cultures were fixed and prepared for immunocytochemistry or ISHH.

Immunocytochemistry. After treatment, slice explants on coverslips were fixed with $4 \%$ formaldehyde in PBS for $1 \mathrm{hr}$ and then washed several times with PBS. Cultures were blocked for $1 \mathrm{hr}$ in $10 \% \mathrm{NGS} / 0.3 \%$ Triton $\mathrm{X}-100$, washed in PBS, and incubated in TH antibody (1:5000; Eugene Tech, Allendale, NJ) overnight at $4^{\circ} \mathrm{C}$. The following day, cultures were washed in PBS and incubated in biotinylated secondary antibody (1:500; Vector, Burlingame, CA) in PBS/0.3\% Triton X-100 for $1 \mathrm{hr}$. The cultures were washed with PBS, incubated with avidin-biotin-horseradish peroxidase complex (Elite 1:600; Vector) in PBS/0.3\% Triton X-100 for $1 \mathrm{hr}$, and rinsed with PBS, and the complex was visualized using 3'3-diaminobenzidine and glucose oxidase (Wray et al., 1988). After the reaction, cultures were counterstained with $0.5 \%$ methyl green, dehydrated in ethanol, cleared in xylene, and mounted.

In situ hybridization histochemistry. ISHH was performed as described previously (Wray et al., 1991) with slight modifications. Briefly, slice explants were fixed in $4 \%$ formaldehyde, rinsed in PBS, permeabilized in $0.3 \%$ Triton X-100/0.05 м EDTA/0.1 м Tris buffer, rinsed in Tris buffer, washed in $0.25 \%$ acetic anhydride $/ 0.1 \mathrm{~m}$ triethanolamine hydrochloride$0.9 \% \mathrm{NaCl}$, rinsed in $2 \times \mathrm{SSC}$, dehydrated through ethanol, delipidated in chloroform, rinsed in ethanol, and air-dried. A 48 oligonucleotide probe (5 pmol), complementary to the coding region of rat TH (bases 867-914) (Grima et al., 1985), was $3^{\prime}$ end-labeled with $\left[\mathrm{S}^{35}\right] \mathrm{dATP}$ (specific activity, 1000-1500 Ci/mmol; DuPont-NEN, Boston, MA), $100 \mathrm{U}$ terminal deoxynucleotidyl transferase (Boehringer Mannheim), and $5 \times$ Tailing buffer (Life Technologies) to a specific activity of $10,000-18,000 \mathrm{Ci} / \mathrm{mmol}$. Labeled probe $(500,000 \mathrm{cpm})$ was applied to each culture in $25 \mu \mathrm{l}$ of hybridization buffer [ $4 \times$ SSC, $50 \%$ formamide, $10 \%$ dextran sulfate, 250 $\mu \mathrm{g} / \mathrm{ml}$ yeast tRNA, $500 \mu \mathrm{g} / \mathrm{ml}$ sheared single stranded salmon sperm DNA, $1 \times$ Denhardt's solution, and $100 \mathrm{~mm}$ dithiothreitol (DTT)]. Cultures were hybridized overnight in humid chambers at $37^{\circ} \mathrm{C}$. The following day, cultures were rinsed in $1 \times \mathrm{SSC} / 65 \mathrm{~mm}$ DTT, washed at high stringency in $2 \times \mathrm{SSC} / 50 \%$ formamide $/ 41 \mathrm{~mm} \mathrm{DTT}$ at $45^{\circ} \mathrm{C}$, followed by $2 \times \mathrm{SSC} / 50 \%$ formamide at $45^{\circ} \mathrm{C}$ without DTT, and washed in $1 \times \mathrm{SSC}$ at room temperature. Cultures were then rinsed in water, dehydrated in ethanol, dried, and placed against film. After x-ray film exposure for $3 \mathrm{~d}$, the cultures were dipped in NTB3 (Eastman Kodak, Rochester, NY) and exposed for $14 \mathrm{~d}$. Emulsion-covered cultures were developed in Dektol (Eastman Kodak) at $15^{\circ}-17^{\circ} \mathrm{C}$, rinsed in water, and fixed with Kodak fixer, then counterstained with $0.5 \%$ methyl green, dehydrated in ethanol, cleared in xylene, and mounted with Permount. Frozen rat brain sections were used as positive controls and were treated with ISHH procedures identical to those for cultures. A second probe generated against rat TH cDNA (bases 631-680) (Grima et al., 1985) produced similar results (data not shown).

Quantitation and statistical analyses of single cell data. Images were digitized using an image analysis system consisting of a Sony CCD Video Camera Module Model XC-77, Power Macintosh 7100/80, Zeiss upright microscope, and National Institutes of Health (NIH) Image Software (Wayne Rasband, NIH, Bethesda, MD). All statistical comparisons were calculated with StatView (Abacus Concepts, Berkeley, CA).

To compare average cell size of TH-immunostained cells from different anatomical regions, $50 \mathrm{TH}$-immunostained cells from three to five cultures from each region were digitized under bright-field microscopy, and area measurements/cell, expressed as $\mu \mathrm{m}^{2}$, were calculated. Differences were analyzed using an ANOVA with a Fisher's PSLD post hoc comparison.

Quantitation of mRNA was performed as described previously (Wray et al., 1991). TH mRNA levels within single cells were examined by measuring integrated densities of silver grains over a cell and the cell area enclosing silver grains; within an individual culture, all discernible single cells were analyzed. Silver grains deposited on labeled cells, initially detected under dark-field microscopy, were digitized under bright-field microscopy, and mean optical density (O.D.) measurements (15\% above background) per cell area, expressed as O.D. $/ \mu \mathrm{m}^{2}$, were calculated for single cells and local background. The value was then multiplied by the highlighted cell area to obtain a total TH mRNA level per cell (O.D./ cell). Local background multiplied by the measured background cell area was subtracted from each cell measurement to obtain a corrected $\mathrm{TH}$ mRNA level per single cell:

$\left(\right.$ Area $_{\text {cell }} \times$ Mean $\left._{\text {cell }}\right)-$

$$
\text { (Area } \left.a_{\text {background }} \times \text { Mean }_{\text {background }}\right)
$$

$=$ mRNA level/cell.

For a population of cells within a given treatment group, a range of mRNA levels per cell is observed, with the frequency distribution being positively skewed (Zoeller et al., 1988; Wray et al., 1989) (also see Fig. 5). Therefore, significant differences between two treatment groups were calculated using the Kolmogorov-Smirnov test for nonparametric data. Because slice explant cultures were generated on different dates and processed for ISHH separately (batch I and batch II), within each anatomical region mRNA levels per cell from batch II were normalized to those of batch I by multiplying values in batch II by the ratio of control mean batch $\mathrm{I} /$ control mean batch II in each region. In the $\mathrm{AH}$ (ratio = 3.01), the frequency distribution of all controls in batch I $(n=870$ cells from eight cultures) was not significantly different (Kolmogorov-Smirnov test, $p<0.05)$ from controls in batch II $(n=270$ cells from four cultures $)$ after normalization. Similarly, in the MH (factor $=1.37$ ), batches I and II ( $n=943$ and 763, from seven and five cultures, respectively) and $\mathrm{CH}$ (factor $=1.72)$, batches I and II $(n=570$ and 207, from four and three cultures, respectively), no significant differences were observed between control populations of each batch within a given region. After this analysis, treatment groups were normalized using the ratios given. The mRNA levels per cell of all cells within a treatment group in a given region were then pooled to create a frequency distribution.

$\mathrm{AH}, \mathrm{MH}$, and $\mathrm{CH}$ cultures were treated with actinomycin D or DRB for $0,8,16$, or $40 \mathrm{hr}$. Nonlinear regression curves of TH mRNA turnover were generated from the median value of each group frequency distribution using a one-phase exponential decay equation (Prism, GraphPad, San Diego, CA). The median, defined as the value in which $50 \%$ of all values of a population fall above and below, was used for the turnover 
calculations, because it is a better measure of central tendency in skewed distributions. $T_{1 / 2}$ values were estimated as the time when the level $\mathrm{TH}$ mRNA per cell was one half of the maximum $(t=0)$. All data were analyzed by one investigator to minimize sampling error. Data from the $\mathrm{MH}$, which was reanalyzed by a second investigator, confirmed the turnover results (batch factor normalization $=1.04$ ) for batches I and II ( $n=500$ and 404, from seven and five cultures, respectively) and was used to determine TH mRNA turnover in that region.

\section{RESULTS}

A parasagittal section of the preoptic area/hypothalamic region from a neonatal rat brain illustrating the TH-containing cells examined is shown in Figure $1 A$. The locations of the coronal sections taken for culturing $(\mathrm{AH}, \mathrm{MH}$, and $\mathrm{CH})$ are marked below the figure. From each of the three distinct anatomical regions, an example of an in vivo coronal section before culturing and immunocytochemically stained for $\mathrm{TH}$ is shown (Fig. $1 B-D$ ).

Slice explants from each anatomical region, maintained for $18 \mathrm{~d}$ in culture and immunostained for $\mathrm{TH}$, are shown in Figure $2 A-C$. In vitro slice explants spread and thinned to a few cells in thickness (Wray et al., 1988). Some cultures maintained their initial shape (see Fig. $2 B$ ), whereas others opened laterally at the position of the third ventricle (see Fig. $2 A$ ). Comparable slice explant cultures processed for ISHH show TH mRNA labeling in single cells (Fig. 2D-F). Note similar positions of $\mathrm{TH}$-immunostained and TH mRNA-labeled neurons among cultures from the same region (compare Fig. 2, $A$ and $D, B$ and $E, C$ and $F$ ).

Initial experiments suggested that size differences exist among the different populations of DA neurons in vitro. Therefore, sizes of TH-immunostained cells from slice explants from different anatomical regions were examined. TH-immunostained cells maintained in slice explant culture were significantly different from each other $(p<0.05$, ANOVA). The average THcontaining perikarya $(n=50)$ was $209 \pm 13,173 \pm 11$, and $146 \pm$ $6 \mu \mathrm{m}^{2}$ in the $\mathrm{AH}, \mathrm{MH}$, and $\mathrm{CH}$, respectively. In $\mathrm{TH}-$ immunostained sections from postnatal day 5 tissue in vivo, cells $(n=10)$ were $242 \pm 20,111 \pm 9$, and $105 \pm 10 \mu \mathrm{m}^{2}$ in the $\mathrm{AH}$, $\mathrm{MH}$, and $\mathrm{CH}$, respectively.

Baseline levels of TH mRNA in control cells from each anatomical region were examined (Fig. 3). Mean and median levels of TH mRNA in single cells for TH-labeled neurons were 28448 and 18636, 19688 and 15351, and 19213 and 10932 O.D. U in the AH, $\mathrm{MH}$, and $\mathrm{CH}$ regions, respectively (see Table 1 ). The frequency distribution of TH mRNA levels in each population (Fig. 4) differs significantly from that of the other two (Kolmogorov-Smirnov test, $p<0.001$ ). If cell size is considered (see above) and an estimate of TH mRNA per cell area (in arbitrary units) is calculated using each population median, then TH-containing interneurons of the AH and MH express 89.1 and 87.7 O.D. U/ $/ \mu \mathrm{m}^{2}$, respectively. $\mathrm{TH}$ cells of the $\mathrm{CH}$ contain less $\mathrm{TH}$ mRNA per cell area (74.9 O.D. $\mathrm{U} / \mu \mathrm{m}^{2}$ ). Clearly, in vitro $\mathrm{TH}$-containing neurons in the $\mathrm{AH}$ and $\mathrm{MH}$ are larger and contain more $\mathrm{TH}$ mRNA than those in the CH. Similar size and mRNA differences in postnatal hypothalamic DA neurons have been reported in vivo (Daikoku et al., 1986; Arbogast and Voogt, 1991b).

DRB and actinomycin D, which act at pharmacologically discrete steps of transcription (Sobell, 1973; Marshall and Price, 1995), were used to block mRNA transcription and estimate TH mRNA degradation or turnover in each region. Slice explant cultures were treated with $150 \mu \mathrm{M}$ DRB or $4 \mu \mathrm{M}$ actinomycin D (Vyas et al., 1990; Czyzyk-Krzeska et al., 1994a) and fixed for ISHH (Fig. $5 A-C$ ) or immunocytochemistry (Fig. $5 D-F$ ) at 0,8 , 16 , or $40 \mathrm{hr}$. Slice explants from each region contained $\mathrm{TH}-$

\begin{tabular}{|c|c|c|c|}
\hline Region & $\begin{array}{l}\text { Treat- } \\
\text { ment } \\
\text { (hr) }\end{array}$ & DRB & Act D \\
\hline \multirow{4}{*}{$\mathrm{AH}$} & 0 & $28448 \pm 804(1140,12)$ & $28448 \pm 804(1140,12)$ \\
\hline & 8 & $24332 \pm 2847(140,4)^{a}$ & $18026 \pm 1002(368,4)^{a}$ \\
\hline & 16 & $10079 \pm 548(404,5)^{a, b}$ & $6767 \pm 360(555,4)^{a, b}$ \\
\hline & 40 & $5328 \pm 232(657,4)^{a, b, c}$ & $7049 \pm 335(461,4)^{a, b}$ \\
\hline \multirow[t]{4}{*}{$\mathrm{MH}$} & 0 & $16908 \pm 295(904,12)$ & $16908 \pm 295(904,12)$ \\
\hline & 8 & $10619 \pm 918(91,2)^{a}$ & $11552 \pm 456(197,4)^{a}$ \\
\hline & 16 & $9999 \pm 346(432,6)^{a}$ & $11312 \pm 327(353.3)^{a}$ \\
\hline & 40 & $8625 \pm 387(111,3)^{a}$ & $7311 \pm 594(47,3)^{a}$ \\
\hline \multirow[t]{4}{*}{$\overline{\mathrm{CH}}$} & 0 & $19213 \pm 750(777,7)$ & $19213 \pm 750(777,7)$ \\
\hline & 8 & $10224 \pm 902(308,3)^{a}$ & $8909 \pm 631(255,4)^{a}$ \\
\hline & 16 & $6521 \pm 604(274,5)^{a, b}$ & $4746 \pm 181(405,3)^{a, b}$ \\
\hline & 40 & $3862 \pm 398(77,1)^{a, b}$ & $4554 \pm 454(108,3)^{a, b}$ \\
\hline
\end{tabular}

Explant cultures were treated with $150 \mu \mathrm{M}$ DRB or $4 \mu \mathrm{M}$ Act D for $0,8,16$, or $40 \mathrm{hr}$ and then processed for ISHH. After hybridization, cultures were dipped in NTB3 autoradiography emulsion and developed after $14 \mathrm{~d}$. TH mRNA levels per cell (O.D./cell) were measured and mean \pm SE ( $n$ cells, $n$ cultures) for each anatomical reigon are shown.

${ }^{a} p<0.001$ from $0 \mathrm{~h}$ using the Kolmogorov-Smirnov two-sample test. ${ }^{b} p<0.001$ from $8 \mathrm{~h}$ using the Kolmogorov-Smirnov two-sample test.

${ }^{c} p<0.001$ from $16 \mathrm{~h}$ using the Kolmogorov-Smirnov two-sample test.

immunostained cells after incubation with DRB or actinomycin D at the times indicated (Fig. $5 D-F$ ), showing that the treatments did not simply eliminate TH-containing neurons and that cultures remained viable. Table 1 shows mean TH mRNA levels per cell for each treatment group and statistical differences among groups (Kolmogorov-Smirnov test, $p<0.001$ ). Using these measurements with both transcription inhibitors, turnover rates of $\mathrm{TH}$ mRNA in the $\mathrm{AH}, \mathrm{MH}$, and $\mathrm{CH}$ can be approximated as $<16$, $>16$, and $<9 \mathrm{hr}$, respectively. However, in all regions examined, TH mRNA per cell per population has a skewed, rather than normal, distribution (see Fig. 4). This has been shown for other cell types in vitro (Wray et al., 1989) and in vivo (Zoeller et al., 1988). Because of the skewed distribution, extreme values are weighted more heavily than those near the mean when calculating the mean. To avoid this bias, the median, defined as the value in which $50 \%$ of all values of a population fall above and below, was the measure of central tendency used to generate curves and estimate TH mRNA turnover (Fig. $6 A-C$ ). $T_{1 / 2}$ values were calculated as the time when the TH mRNA level per cell was one half of maximum $(t=0)$. Using median values, $t_{1 / 2}$ TH mRNA estimates are 12 and 9, 11 and 23, and 6 and $7 \mathrm{hr}$ for DRB and actinomycin $\mathrm{D}$ in the $\mathrm{AH}, \mathrm{MH}$, and $\mathrm{CH}$ regions, respectively. The two transcription inhibitors produced similar $t_{1 / 2}$ estimates, and nearly superimposable curves, within the $\mathrm{AH}$ and $\mathrm{CH}$ regions.

\section{DISCUSSION}

The present work examines the intrinsic regulation of gene expression of a single phenotypic marker, $\mathrm{TH}$, in subpopulations of DA forebrain neurons. Anatomically distinct DA populations of the hypothalamus were established and maintained in vitro in long-term organotypic slice explants. We report marked differences in the post-transcriptional regulation of TH mRNA within these populations. Basal TH mRNA levels in DA neuroendocrine cells of the $\mathrm{CH}$ were considerably lower and displayed the fastest turnover of TH mRNA, compared with levels for rostral DA 

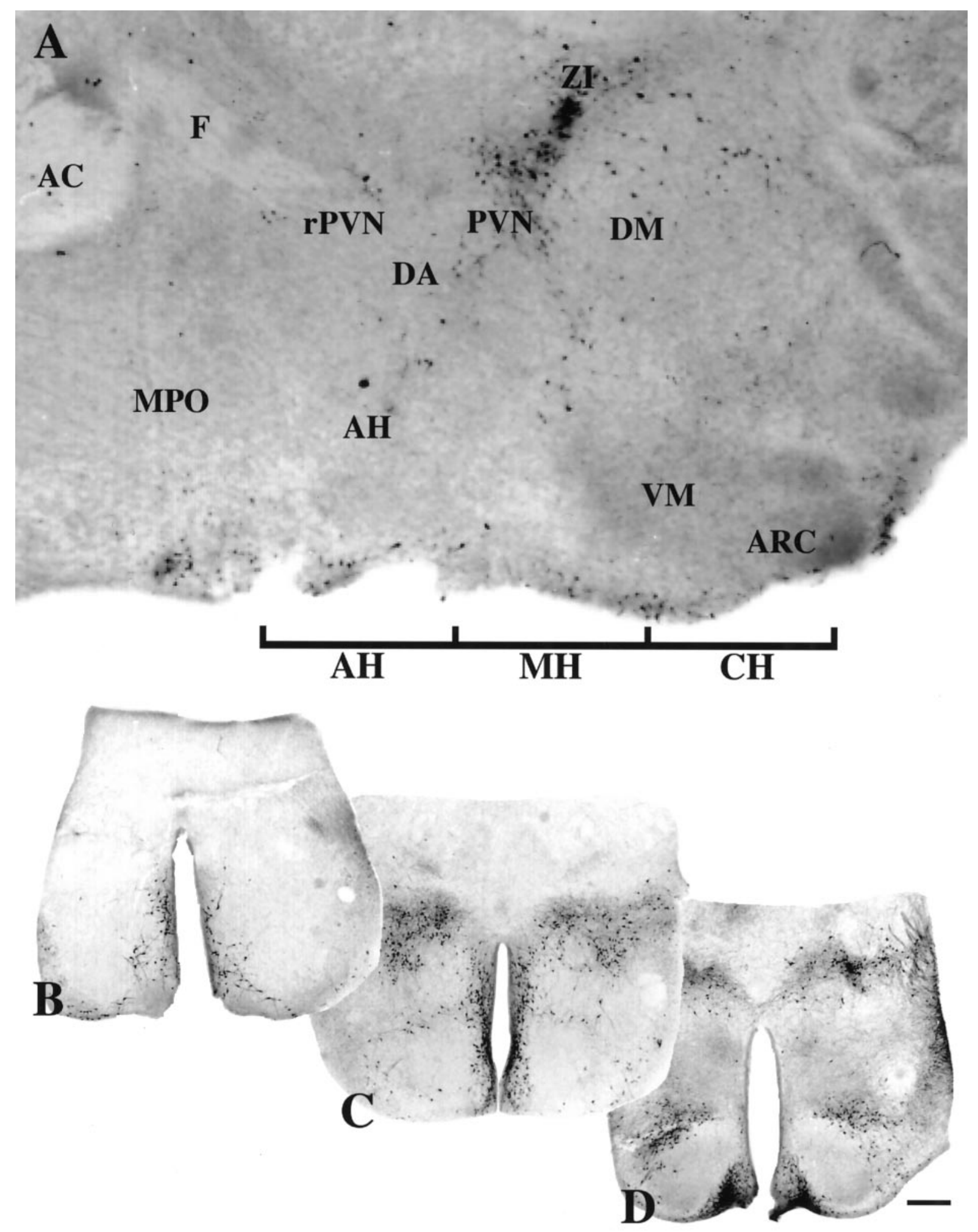

Figure 1. TH neuronal populations examined in slice explants. $A$, TH-immunostained parasagittal section of preoptic/hypothalamic area of a neonatal rat brain. Rostral is to the left. The positions of the slices taken for culturing are indicated ventrally. Three $800 \mu \mathrm{m}$ culture areas $(\mathrm{AH}$, $\mathrm{MH}$, and $\mathrm{CH})$ containing two $400 \mu \mathrm{m}$ sections per area were used in these studies. Representative coronal views of tissue sections on the day of culturing immunostained for TH; three DA neuronal areas, $\mathrm{AH}(B), \mathrm{MH}(C)$, and $\mathrm{CH}(D)$, are shown below. Scale bar, $500 \mu \mathrm{m}$. $A C$, Anterior commissure; $A H$, anterior hypothalamus; $A R C$, arcuate nucleus; $D A$, dorsal area of the hypothalamus; $D M$, dorsomedial nucleus of the hypothalamus; $F$, fornix; $M P O$, medial preoptic area; $M H$, periventricular region of the hypothalamus; $P V N$, paraventricular nucleus; $r P V N$, rostral paraventricular nucleus of the hypothalamus; $V M$, ventromedial nucleus of the hypothalamus; $Z I$, zona incerta. 

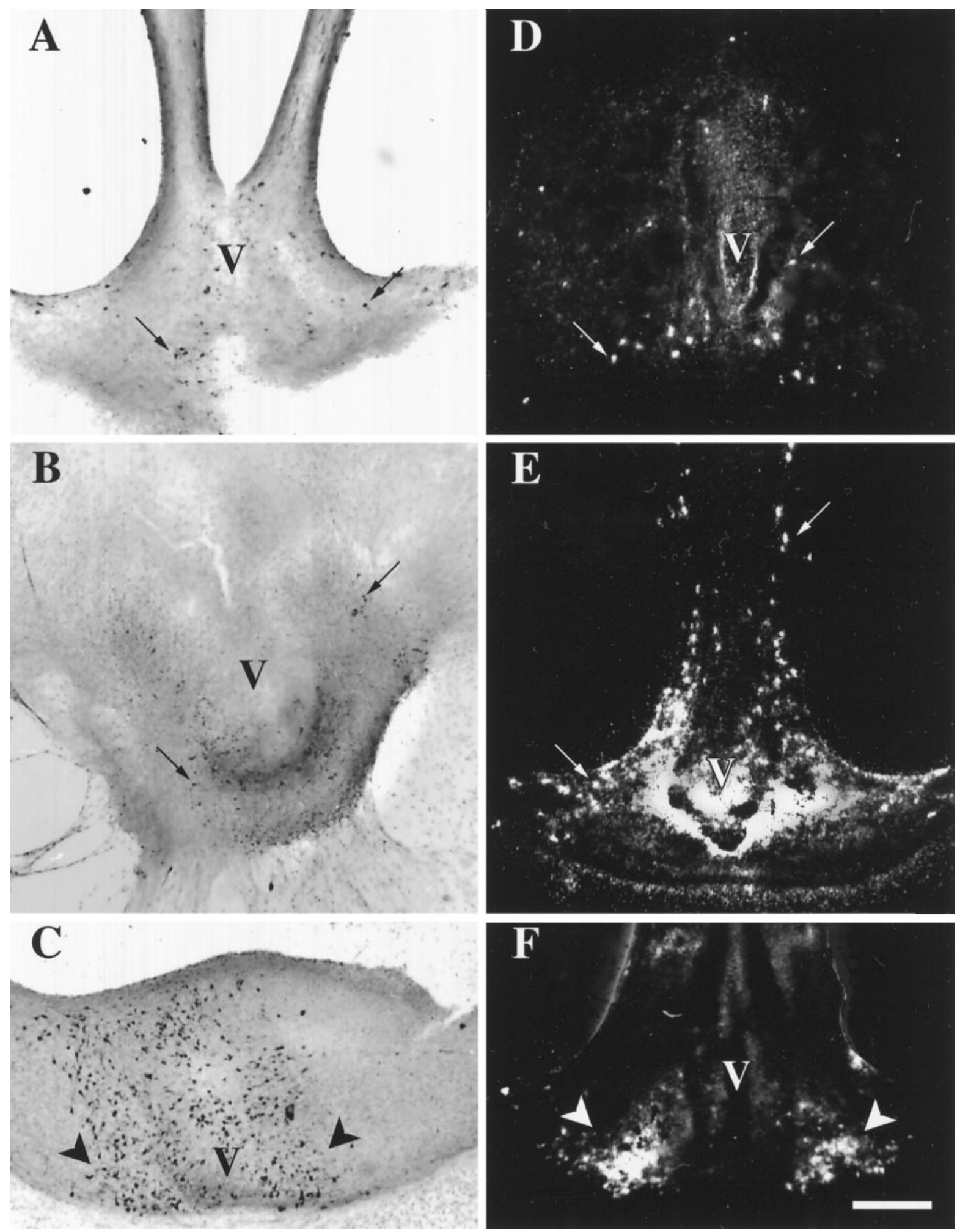

Figure 2. TH-expressing cells from three regions of the preoptic area/hypothalamus maintained in slice explant cultures for $18 \mathrm{~d}$ in vitro. $A-C$ were immunocytochemically stained using an antibody against TH (bright-field photomicrographs). $D-F$ were processed by ISHH using a synthetic deoxynucleotide antisense probe for TH mRNA (dark-field photomicrographs). $A$ and $D$ are cultures from the medial preoptic/anterior hypothalamic region ( $A H$ in Fig. 1); $B$ and $E$ are cultures from the periventricular region of the hypothalamus at the level of the paraventricular nucleus and zona incerta ( $M H$ in Fig. 1 ); and $C$ and $F$ are cultures from caudal hypothalamic regions containing the arcuate nucleus $(C H$ in Fig. 1$)$. $V$, Third ventricle. Black arrows point to a few individual TH-immunopositive neurons $(A, B)$; white arrows point to a few of the cells expressing TH mRNA as indicated by clusters of white silver grains over cell soma regions. Arrows in $C$ and $F$ indicate the arcuate nucleus containing large numbers of TH-immunopositive neurons $(C)$ and cells expressing TH mRNA $(F)$. Scale bar, $500 \mu \mathrm{m}$. 

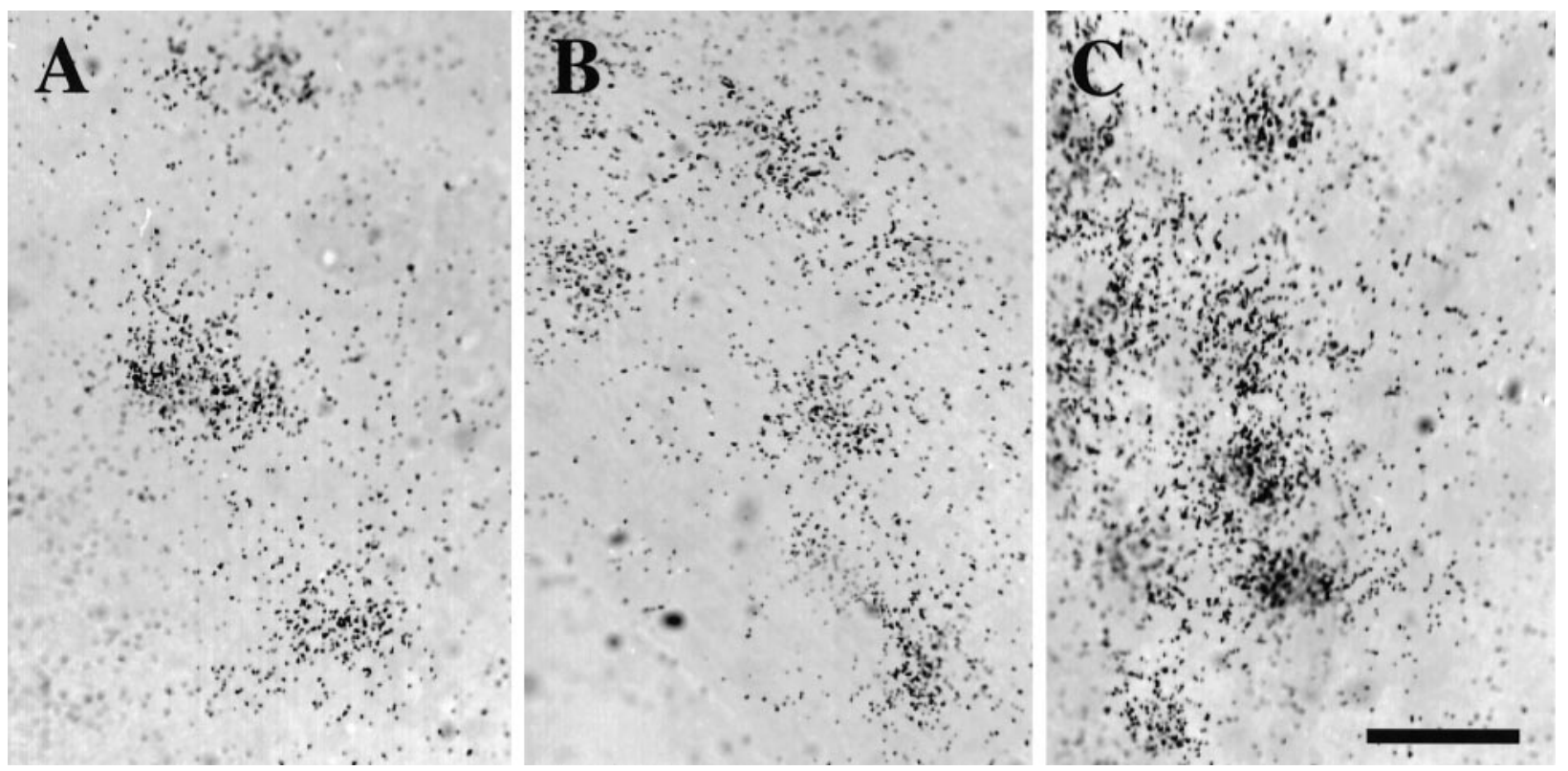

Figure 3. Single cells expressing TH mRNA were visualized by ISHH and O.D. measurements/cell for each of three anatomical regions analyzed. Cells expressing TH mRNA (clusters of silver grains $15 \%$ more than background) were detected in control explants from the $\mathrm{AH}(A)$, $\mathrm{MH}(B)$, and $\mathrm{CH}(C)$. Scale bar, $50 \mu \mathrm{m}$.

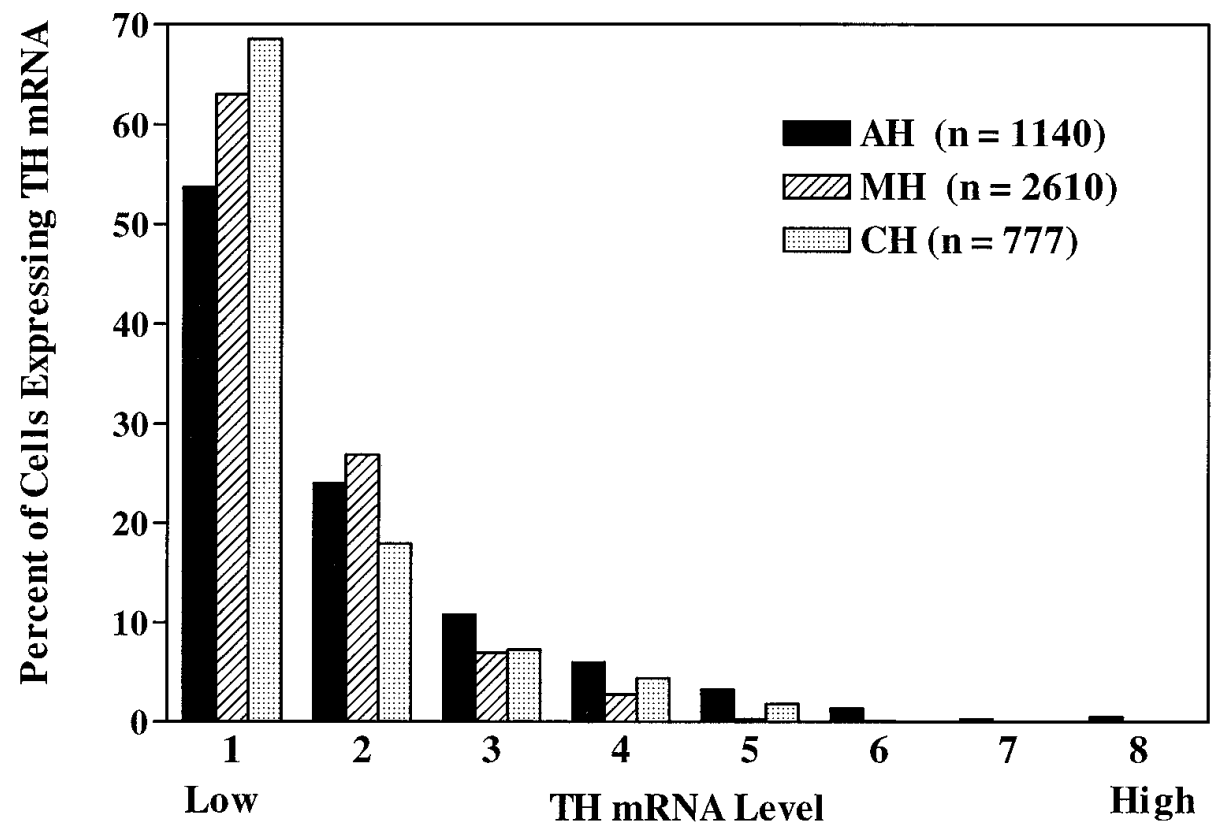

Figure 4. Frequency distributions of the hybridization signal intensities (TH mRNA level per cell) of individual labeled cells from control cultures from each anatomical region hybridized with a probe against TH mRNA. The total range of TH mRNA level per cell values was divided into eight bins; bin 1 contains cells with the lowest levels of TH mRNA, whereas bin 8 contains those with the highest levels. Frequency distributions of TH mRNA levels of single cells in cultures from each anatomical region were significantly different (KolmogorovSmirnov test, $p<0.001)$. populations. We propose that intrinsic differences in the posttranscriptional regulation of $\mathrm{TH}$ permit neuronal subpopulations, which subserve different physiological functions, an additional mechanism to control DA biosynthesis in response to their unique needs.

This study is the first to compare basal TH mRNA turnover rates in anatomically defined populations of CNS DA neurons. Previously, in dissociated cultures of rat hypothalami, TH mRNA turnover after stimulation with forskolin was estimated as $\sim 14 \mathrm{hr}$ (Kedzierski et al., 1994). However, several populations of DA neurons are present within the preoptic area/hypothalamus (for review, see Moore and Lookingland, 1995). In the AH, THcontaining neurons, part of the rostral A14 DA cell group, lie adjacent to the third ventricle. These DA neurons, which are positioned rostral to the suprachiasmatic nuclei and project locally to the medial preoptic nucleus and anterior hypothalamic area, have been co-localized with substance P (Seroogy et al., 1988), cholecystokinin, and neurotensin (Ibata et al., 1984). Evidence indicates that these DA interneurons are regulated by dopamine receptor-mediated mechanisms and regulate reproductive function (Summerhill et al., 1987; Pehek et al., 1988; Gonzalo-Ruiz et al., 1992; Rasmussen et al., 1992). MH sections (at the level of the paraventricular nucleus) contain at least three anatomically distinct populations of TH-containing neurons. Within this region, some periventricular DA neurons (still classified as A14) receive input from corticotropin-releasing hormone neurons and may 

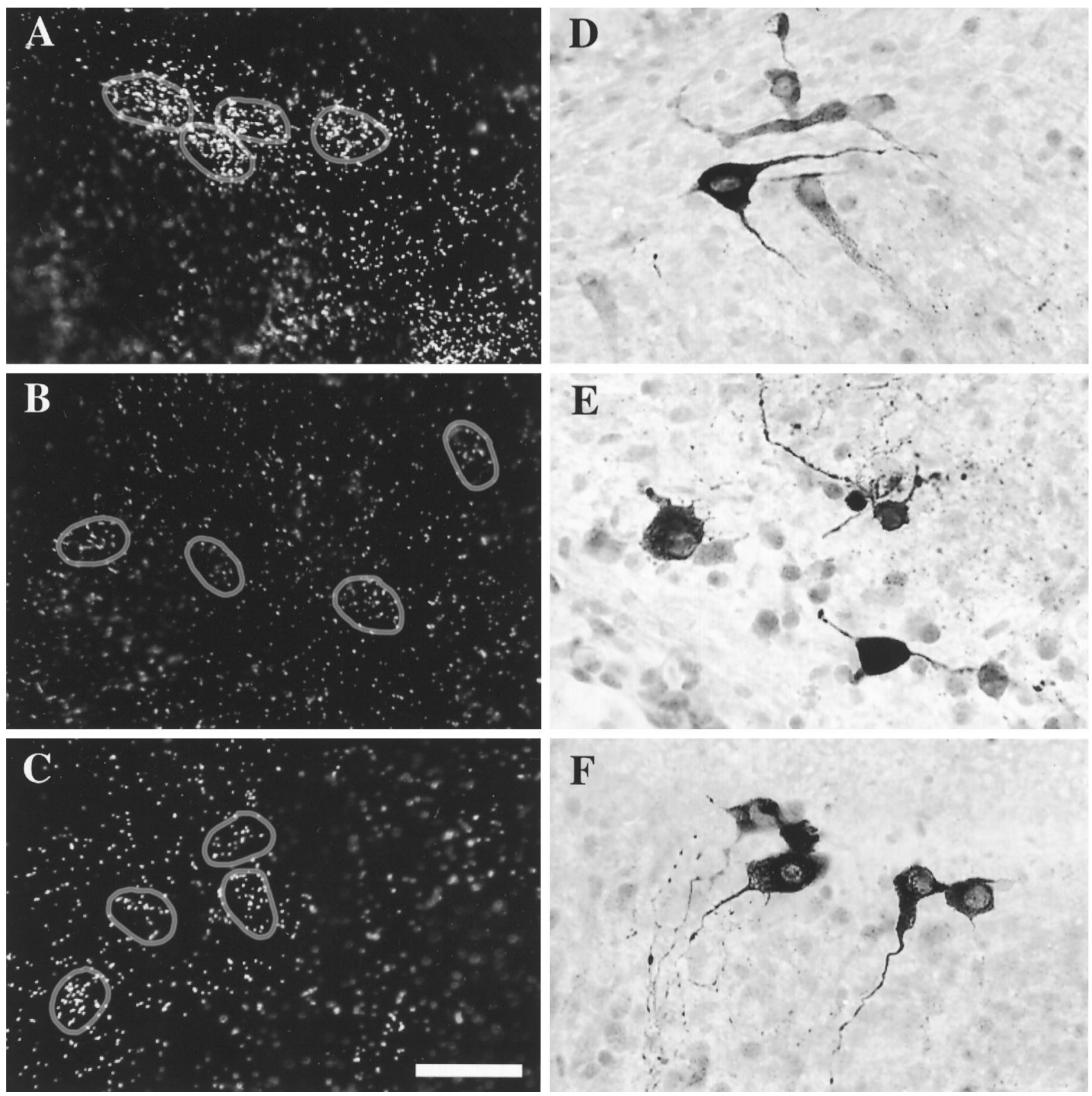

Figure 5. Transcription inhibitors decreased TH mRNA, but TH-immunopositive cells were still detectable. After a $40 \mathrm{hr}$ exposure to transcription inhibitors $(B, E$, DRB; $C, F$, actinomycin D), TH mRNA levels decreased significantly (compare with control $A$ ), yet immunostaining revealed numerous TH-positive cells (compare with control $D$ ). All explants shown here are from the region of the $\mathrm{CH}$. Circles in $D-F$ indicate cells expressing TH mRNA. Scale bar, $50 \mu \mathrm{m}$.

modulate stressor effects (Thind and Goldsmith, 1989). A more rostrocaudal subpopulation of A14 DA neurons within the MH sections is the periventricular-hypophysial DA neuron subpopulation; neurons in this group project to the intermediate lobe of the posterior pituitary (Daikoku et al., 1986) and tonically inhibit $\alpha$-melanocyte-stimulating hormone secretion from pituitary melanotrophs (Goudreau et al., 1992). The perikarya of DA neurons in the zona incerta (A13) are also found within sections from the $\mathrm{MH}$. These incertohypothalamic neurons project within (Björklund et al., 1975) and outside the hypothalamus [e.g., to the septum, bed nucleus of the stria terminalis, and diagonal band of Broca (Wagner et al., 1995), and may modulate the estrous cycle (James et al., 1987; Sanghera et al., 1991)]. Finally, the caudalmost hypothalamic sections $(\mathrm{CH})$ contain the TH-containing tuberoinfundibular neurons of the arcuate nucleus (A12). These neuroendocrine cells project to the median eminence, release dopamine into the hypophysial portal circulation, inhibit prolactin release from pituitary lactotrophs, and downregulate in response to feedback control by prolactin (for review, see Neill and Nagy, 1994).

Slice explant cultures from the preoptic area to the $\mathrm{CH}$ were generated to experimentally isolate forebrain DA subpopulations. These explants retained much of the cytoarchitecture present in original tissues, thus allowing for examination of primary DA neurons in an "organotypic" environment. Because cultures were maintained in defined medium for 1 week before experimentation, unknown factors present in serum-containing medium and effects of circulating hormones typically encountered in vivo were avoided. DA neurons in explants from the three hypothalamic regions displayed significantly different basal TH mRNA levels 

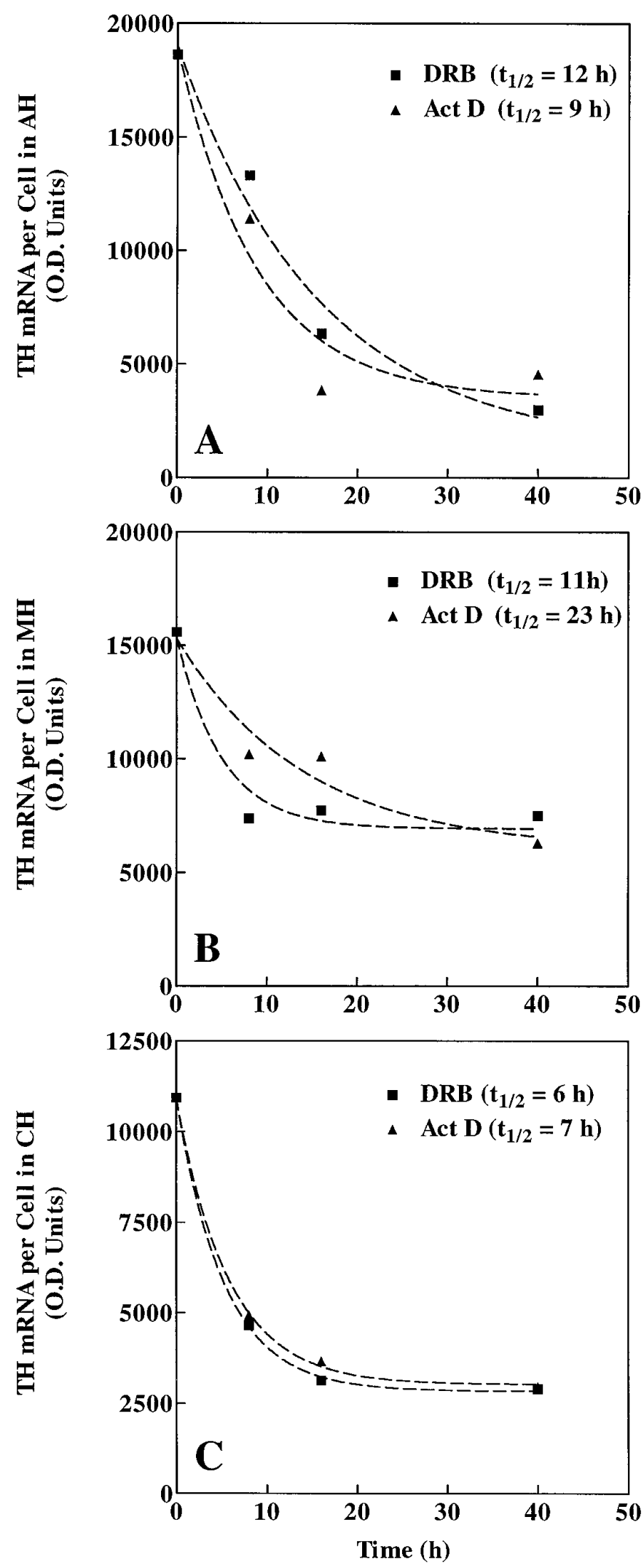

Figure 6. Explant cultures were treated with $150 \mu \mathrm{M}$ DRB or $4 \mu \mathrm{M}$ actinomycin D $(A c t D)$ for $0,8,16$, or $40 \mathrm{hr}$ and then processed for ISHH. For each anatomical region $(A, A H ; B, M H$; and $C, C H)$, TH mRNA levels per cell (O.D./cell) were measured, and the median value of each treatment group was plotted to calculate TH mRNA turnover. and soma sizes, with those in the $\mathrm{CH}$ being the lowest and smallest, respectively. Similar differences in TH mRNA levels and cell size have been observed in vivo in adult and postnatal rat hypothalami (Van den Pol et al., 1984; Arbogast and Voogt, 1991b). In addition, an increase in TH mRNA levels between postnatal day 5 tissue and explants maintained in culture for $18 \mathrm{~d}$ was observed (data not shown) that parallel the increase observed in vivo during this time (Arbogast and Voogt, 1991b). Overall, these findings suggest that many aspects of maturation of DA systems occurs in slice explant culture and that baseline differences between TH-containing populations present in vivo (i.e., size and basal TH mRNA levels) exist in vitro as well.

Recently, in PC12 cells, a hypoxia-inducible protein (HIP) was shown to bind TH mRNA and increase its $t_{1 / 2}$ from 10 to $30 \mathrm{hr}$ (Czyzyk-Krzeska et al., 1994a,b). The protein is induced after a 3 hr exposure to hypoxic conditions (Czyzyk-Krzeska and Beresh, 1996), suggesting that this form of $\mathrm{TH}$ regulation is fairly rapid. Furthermore, recent data showing the TH mRNA/HIP complex in carotid bodies, superior cervical ganglia, adrenal glands, and brain extracts (Beresh and Czyzyk-Krzeska, 1996) indicate that this mechanism of TH mRNA stabilization may occur throughout the nervous system. Therefore, HIP binding could be a characteristic mode of TH mRNA stabilization, although agents other than hypoxia that induce HIP have yet to be found. We report that the AH has a TH mRNA $t_{1 / 2}$ of $9-12 \mathrm{hr}$, suggesting that HIP levels in this region may reflect those in normoxic PC12 cells. $\mathrm{MH}$ DA neurons may also be regulated by HIP, but compared with the other populations examined, MH DA neurons exhibit a large range in estimated $\mathrm{TH}$ mRNA turnover. This range probably does not result from a sexually dimorphic difference (Manzanares et al., 1992), because no differences in basal TH mRNA levels were observed in $\mathrm{MH}$ controls after $18 \mathrm{~d}$ in culture (KolmogorovSmirnov test, $p>0.01$ ). However, several other factors may have contributed to the observed range. First, as discussed previously, at least three anatomically and functionally distinct populations of DA neurons exist in the MH. Second, populations within this region may have differential sensitivities to the two inhibitors used, each of which acts at a pharmacologically discrete step of transcription (Sobell, 1973; Marshall and Price, 1995) on the transcript of interest and on that of other potential regulators of mRNA stability. Third, functionally distinct DA populations within the $\mathrm{MH}$ may maintain different basal levels of HIP. Any one of these factors alone or in combination with the others may explain the range in TH mRNA turnover observed in the $\mathrm{MH}$.

In contrast to the $\mathrm{MH}$ and $\mathrm{AH}$, the $\mathrm{CH}$ has an estimated $\mathrm{TH}$ mRNA half-life of 6-7 hr, a basal rate that is less than that observed in normoxic PC12 cells (Czyzyk-Krzeska et al., 1994a), suggesting that these neuroendocrine cells exhibit an alternative mechanism to regulate $\mathrm{TH}$ mRNA degradation. Indeed, the DA neuroendocrine cells of the arcuate nucleus differ from other TH-containing populations of the hypothalamus in many respects. Early work in vitro shows that the rate of dopamine synthesis in the median eminence and hence in terminals of arcuate DA neurons is 4 or $7 \times$ faster than that in the arcuate nucleus itself or in the residual hypothalamus, respectively (Versteeg et al., 1975). Baseline activity of arcuate DA cells, as estimated by DOPAC levels, appears to be at least 5 times greater than that of incertohypothalamic DA neurons (Eaton et al., 1994) and 10 times greater than that of periventricular-hypophysial DA neurons (Wagner et al., 1994). In total, these studies show that arcuate DA neurons not only release dopamine more often, but synthesize dopamine faster than the other populations. We report here that dopamine cells of the arcuate nucleus have the lowest 
baseline level of TH mRNA of the populations examined. Because TH mRNA levels relate directly to the rate of TH activity (Arbogast and Voogt, 1991a) and TH synthesis (Tank et al., 1986) and previous biochemical studies indicate that these neurons have the highest baseline rate of DA synthesis, arcuate DA neurons may exhibit a higher rate of TH mRNA translation relative to that of the other populations. Foremost, our study demonstrates that arcuate DA cells have the fastest basal TH mRNA turnover rate of the hypothalamic DA neurons examined. Therefore, arcuate DA neurons cease dopamine production more quickly than the other hypothalamic DA populations. These characteristics would be important in a neuronal population that is activated for hourly intervals and then rapidly adjusts activity in response to afferents and/or feedback regulation. In support of this contention, arcuate DA neurons were recently shown to display a semicircadian rhythm in pseudopregnant rats (Timmerman et al., 1995). Fos-related activity, an indicator of neuronal activation, peaked twice daily in arcuate DA neurons in 3-6 hr and subsided to baseline levels within 4-6 hr (Lerant et al., 1996). Similarly, within the suprachiasmatic nucleus, vasopressin peptide (Tominaga et al., 1992) and mRNA levels (Carter and Murphy, 1989; Cagampang et al., 1994) exhibit circadian rhythmicity that may be mediated by changes in vasopressin mRNA stability (Robinson et al., 1988; Carter and Murphy, 1989). Furthermore, this phenomenon occurs in slice explant culture, indicating that changes in vasopressin mRNA stability are not the result of extrinsic signals (Carter and Murphy, 1989). Arcuate DA neurons, therefore, may also rely on changes in TH mRNA stability to regulate their own rhythmic secretion of DA.

\section{REFERENCES}

Arbogast LA, Voogt JL (1991a) Hyperprolactinemia increases and hypoprolactinemia decreases tyrosine hydroxylase messenger ribonucleic acid levels in the arcuate nuclei, but not the substantia nigra or zona incerta. Endocrinology 128:997-1005.

Arbogast LA, Voogt JL (1991b) Ontogeny of tyrosine hydroxylase mRNA signal levels in central dopaminergic neurons: development of a gender difference in the arcuate nuclei. Brain Res Dev Brain Res 63:151-161.

Atwater JA, Wisdom R, Verma IM (1990) Regulated mRNA stability. Annu Rev Genet 24:519-541.

Baertschi AJ, Beny JL, Gähwiler B (1982) Hypothalamic paraventricular nucleus is a privileged site for brain-pituitary interaction in long-term tissue culture. Nature 295:145-147.

Beresh JE, Czyzyk-Krzeska MF (1996) Cytidine-rich protein-binding sequence in the $3^{\prime}$ untranslated region of tyrosine hydroxylase mRNA as a determinant of the TH mRNA stability. Soc Neurosci Abstr 22:1559.

Björklund A, Lindvall O, Nobin A (1975) Evidence of an incertohypothalamic dopamine neurone system in the rat. Brain Res 89:29-42.

Cagampang FR, Yang J, Nakayama Y, Fukuhara C, Inouye ST (1994) Circadian variation of arginine-vasopressin messenger RNA in the rat suprachiasmatic nucleus. Brain Res Mol Brain Res 24:179-184.

Carter DA, Murphy D (1989) Diurnal rhythm of vasopressin mRNA species in the rat suprachiasmatic nucleus: independence of neuroendocrine modulation and maintenance in explant culture. Brain Res Mol Brain Res 6:233-239.

Craviso GL, Hemelt VB, Waymire JC (1992) Nicotinic cholinergic regulation of tyrosine hydroxylase gene expression and catecholamine synthesis in isolated bovine adrenal chromaffin cells. J Neurochem 59:2285-2296.

Czyzyk-Krzeska MF, Beresh JE (1996) Characterization of the hypoxiainducible protein binding site within the pyrimidine-rich tract in the 3 -untranslated region of the tyrosine hydroxylase mRNA. J Biol Chem 271:3293-3299.

Czyzyk-Krzeska MF, Furnari BA, Lawson EE, Millhorn DE (1994a) Hypoxia increases rate of transcription and stability of tyrosine hydroxylase mRNA in pheochromocytoma (PC12) cells. J Biol Chem 269:760-764.

Czyzyk-Krzeska MF, Dominski Z, Kole R, Millhorn DE (1994b) Hypoxia stimulates binding of a cytoplasmic protein to a pyrimidine-rich se- quence in the $3^{\prime}$-untranslated region of rat tyrosine hydroxylase mRNA. J Biol Chem 269:9940-9945.

Daikoku S, Kawano H, Okamura Y, Tokuzen M, Nagatsu I (1986) Ontogenesis of immunoreactive tyrosine hydroxylase-containing neurons in rat hypothalamus. Dev Brain Res 28:85-98.

Eaton MJ, Wagner CK, Moore KE, Lookingland KJ (1994) Neurochemical identification of A13 dopaminergic neuronal projections from the medial zona incerta to the horizontal limb of the diagonal band of Broca and the central nucleus of the amygdala. Brain Res 659:201-207.

Fossom LH, Sterling CR, Tank AW (1992) Regulation of tyrosine hydroxylase gene transcription rate and tyrosine hydroxylase mRNA stability by cyclic AMP and glucocorticoid. Mol Pharmacol 42:898-908.

Fraboulet S, Boudouresque F, Delfino C, Fina F, Oliver C, Ouafik L (1996) Effect of thyroid hormone on peptidylglycine $\alpha$-amidating monooxygenase gene expression in anterior pituitary gland: transcriptional studies and messenger ribonucleic acid stability. Endocrinology 137:5493-5501.

Gonzalo-Ruiz A, Alonso A, Sanz JM, Llinas RR (1992) A dopaminergic projection to the rat mammillary nuclei demonstrated by retrograde transport of wheat germ agglutinin-horseradish peroxidase and tyrosine hydroxylase immunohistochemistry. J Comp Neurol 321:300-311.

Goudreau JL, Lindley SE, Lookingland KJ, Moore KE (1992) Evidence that hypothalamic periventricular dopamine neurons innervate the intermediate lobe of the rat pituitary. Neuroendocrinology 56:100-105.

Greenberg ME, Belasco JG (1993) Control of the decay of labile protooncogene and cytokine mRNAs. In: Control of messenger RNA stability (Belasco JG, Brawerman G, eds), pp 199-218. San Diego: Academic.

Grima B, Lamouroux A, Blanot F, Biguet NF, Mallet J (1985) Complete coding sequence of rat tyrosine hydroxylase mRNA. Proc Natl Acad Sci USA 82:617-621.

Ibata Y, Kawakami F, Fukui K, Okamura H, Obata-Tsuto HL, Tsuto T, Terubayashi H (1984) Morphological survey of neurotensin-like immunoreactive neurons in the hypothalamus. Peptides 5 [Suppl 1] 109-120.

James MD, MacKenzie FJ, Tuohy-Jones PA, Wilson CA (1987) Dopaminergic neurones in the zona incerta exert a stimulatory control on gonadotrophin release via D1 dopamine receptors. Neuroendocrinology 45:348-355.

Kedzierski W, Aguila-Mansilla N, Kozlowski GP, Porter JC (1994) Expression of tyrosine hydroxylase gene in cultured hypothalamic cells: roles of protein kinase A and C. J Neurochem 62:431-437.

Klausner RD, Rouault TA, Harford JB (1993) Regulating the fate of mRNA: the control of cellular iron metabolism. Cell 72:19-28.

Lerant A, Herman ME, Freeman ME (1996) Dopaminergic neurons of periventricular and arcuate nuclei of pseudopregnant rats: semicircadian rhythm in fos-related antigens immunoreactivities and in dopamine concentration. Endocrinology 137:3621-3628.

Levitt M, Spector S, Sjoerdsma A, Udenfriend S (1965) Elucidation of the rate-limiting step in norepinephrine biosynthesis in the perfused guinea-pig heart. J Pharmacol Exp Ther 148:1-7.

Manzanares J, Toney TW, Tian Y, Eaton MJ, Moore KE, Lookingland KJ (1992) Sexual differences in the activity of periventricular-hypophysial dopaminergic neurons in rats. Life Sci 51:995-1001.

Marshall NF, Price DH (1995) Purification of P-TEFb, a transcription factor required for the transition into productive elongation. J Biol Chem 270:12335-12338.

Moore KE, Lookingland KJ (1995) Dopaminergic neuronal systems in the hypothalamus. In: Psychopharmacology: the fourth generation of progress (Bloom FE, Kupfer DJ, eds), pp 245-256. New York: Raven.

Neill JD, Nagy GM (1994) Prolactin secretion and its control. In: The physiology of reproduction (Knobil E, Neill JD, eds), pp 1833-1860. New York: Raven.

Pehek EA, Warner RK, Bazzett TJ, Bitran D, Band LC, Eaton RC, Hull EM (1988) Microinjection of cis-flupenthixol, a dopamine antagonist, into the medial preoptic area impairs sexual behavior of male rats. Brain Res 443:70-76.

Rasmussen DD, Jakubowski M, Allen DL, Roberts JL (1992) Positive correlation between proopiomelanocortin and tyrosine hydroxylase mRNA levels in the mediobasohypothalamus of ovariectomized rats: response to estradiol replacement and withdrawal. Neuroendocrinology 56:285-294.

Robinson BG, Frim DM, Schwartz WJ, Majzoub JA (1988) Vasopressin mRNA in the suprachiasmatic nuclei: daily regulation of polyadenylate tail length. Science 241:342-344.

Saadat S, Stehle AD, Lamouroux A, Mallet J, Thoenen H (1987) Influence of cell-cell contact on levels of tyrosine hydroxylase in cultured bovine adrenal chromaffin cells. J Biol Chem 262:13007-13014.

Sanghera MK, Anselmo-Franci J, McCann SM (1991) Effect of medial 
zona incerta lesions on the ovulatory surge of gonadotrophins and prolactin in the rat. Neuroendocrinology 54:433-438.

Seroogy K, Tsuruo Y, Hökfelt T, Walsh J, Fahrenkrug J, Emson PC, Goldstein M (1988) Further analysis of presence of peptides in dopamine neurons. Cholecystokinin, peptide histidine-isoleucine/vasoactive intestinal polypeptide and substance $\mathrm{P}$ in rat supramammillary region and mesencephalon. Exp Brain Res 72:523-534.

Sobell HM (1973) The stereochemistry of actinomycin binding to DNA and its implications in molecular biology. Prog Nucleic Acid Res Mol Biol 13:153-190.

Summerhill EM, Wood K, Fishman MC (1987) Regulation of tyrosine hydroxylase gene expression during differentiation of neuroblastoma cells. Brain Res 388:99-103.

Tank AW, Curella P, Ham L (1986) Induction of mRNA for tyrosine hydroxylase by cyclic AMP and glucocorticoids in a rat pheochromocytoma cell line: evidence for the regulation of tyrosine hydroxylase synthesis by multiple mechanisms in cells exposed to elevated levels of both inducing agents. Mol Pharmacol 30:497-503.

Thind KK, Goldsmith PC (1989) Corticotropin-releasing factor neurons innervate dopamine neurons in the periventricular hypothalamus of juvenile macaques. Synaptic evidence for a possible companion neurotransmitter. Neuroendocrinology 50:351-358.

Timmerman W, Poelman RT, Westerink BH, Schuiling GA (1995) Semicircadian rhythm of dopamine release in the mediobasal hypothalamus in awake rats during pseudopregnancy: evidence that a thyrotropinreleasing hormone analogue stimulates dopamine release and thereby inhibits prolactin secretion. Neuroendocrinology 62:434-443.

Tominaga K, Shinohara K, Otori Y, Fukuhara C, Inouye ST (1992) Circadian rhythms of vasopressin content in the suprachiasmatic nucleus of the rat. NeuroReport 3:809-812.

Tominaga K, Inouye SI, Okamura H (1994) Organotypic slice culture of the rat suprachiasmatic nucleus: sustenance of cellular architecture and circadian rhythm. Neuroscience 59:1025-1042.
Van den Pol AN, Herbst RS, Powell JF (1984) Tyrosine hydroxylaseimmunoreactive neurons of the hypothalamus: a light and electron microscopic study. Neuroscience 13:1117-1156.

Versteeg DH, Van der Gugten J, Van Ree JM (1975) Regional turnover and synthesis of catecholamines in rat hypothalamus. Nature 256:502-503.

Vyas S, Faucon Biguet N, Mallet J (1990) Transcriptional and posttranscriptional regulation of tyrosine hydroxylase gene by protein kinase C. EMBO J 9:3707-3712.

Wagner CK, Eaton MJ, Moore KE, Lookingland KJ (1995) Efferent projections from the region of the medial zona incerta containing A13 dopaminergic neurons: a PHA-L anterograde tract-tracing study in the rat. Brain Res 677:229-237.

Wagner EJ, Moore KE, Lookingland KJ (1994) Non-NMDA receptormediated regulation of hypothalamic dopaminergic neurons in the rat. Eur J Pharmacol 254:105-112.

Wray S, Gähwiler BH, Gainer H (1988) Slice cultures of LHRH neurons in the presence and absence of brainstem and pituitary. Peptides 9:1151-1175.

Wray S, Zoeller RT, Gainer H (1989) Differential effects of estrogen on luteinizing hormone-releasing hormone gene expression in slice explant cultures prepared from specific rat forebrain regions. Mol Endocrinol 3:1197-1206.

Wray S, Kusano K, Gainer H (1991) Maintenance of LHRH and oxytocin neurons in slice explants cultured in serum-free media: effects of tetrodotoxin on gene expression. Neuroendocrinology 54:327-339.

Zoeller RT, Seeburg PH, Young 3d WS (1988) In situ hybridization histochemistry for messenger ribonucleic acid (mRNA) encoding gonadotropin-releasing hormone $(\mathrm{GnRH})$ : effect of estrogen on cellular levels of GnRH mRNA in female rat brain. Endocrinology 122:2570-2577. 